\title{
COMPLETION OF LEGAL CONFLICTS IN THE IMPLEMENTATION OF THE DECISION OF THE NATIONAL SHARIA ARBITRATION BOARD
}

\author{
Sofian Al Hakim \\ Universitas Islam Negeri Sunan Gunung Djati Bandung \\ Email: sofyanalhakim@uinsgd.ac.id \\ Muhammad Hasanuddin \\ Universitas Islam Negeri Sunan Gunung Djati Bandung \\ Email: muhammadhasanuddin@uinsgd.ac.id \\ Heris Suhendar \\ Institut Agama Islam Negeri Pekalongan \\ Email: heris.suhendar@iainpekalongan.ac.id
}

\begin{abstract}
The background of the article is the contents of Article 59 paragraph (3) and explanation of paragraph (1) of the Law on Judicial Power. The article authorizes the District Court to implement the decision of the Sharia arbitration body on the resolution of Islamic economic disputes. The article and explanation of the verse contradicts the absolute authority of the Religious Courts regulated in Article 49 letter (i) of the Law on Religious Courts. This shows that, the legislators are not consistent in making laws and regulations, so that it creates legal uncertainty. By applying the normative legal research method to the statute approach and case approach, this article seeks to describe the phenomenon of legal conflicts that occur. From the in-depth analysis it can be concluded that the legal provisions regarding the implementation of the decision of the National Sharia Arbitration Board are regulated in the Arbitration Law, the Judicial Power Act and the Religious Courts Act. The legal substance of the provisions therein enables antinomy or legal conflicts. Antinomy settlement can use the principle of lex specialis derogat legi generali
\end{abstract}

Keywords: legal antinomy, legal conflict, harmonization, legal certainty

\section{A. INTRODUCTION}

The stipulation of Law Number 3 of 2006 concerning Religious Courts has brought great changes to the existence of religious justice institutions today (Manan, 2017). The enactment of this law is a form of government alignments through the direction of its political policies in expanding the authority of the Religious Courts to accommodate the needs of Indonesian people who are predominantly Muslim (Fathurrahman Djamil, 2006). This can be seen in Article 49 letter (i) of the Law on Religious Courts. The amendment from the previous law lies in the absolute competence given to the Religious Courts, which before the authority of the Religious Courts were limited to family law matters (Wahyu Widiana, 2007).

Prior to the issuance of the above law, the National Sharia Council of the Indonesian Ulema Council continued to push for the resolution of Islamic economic disputes to be resolved through institutions that possessed human resources who had the qualifications of sharia economic mediation law. These mediators are then assembled in the National Sharia Abitration Agency. This idea was later accommodated as part of the provisions of Bank Indonesia Regulations. This body is a transformation from the previous institution, namely the Muamalat Indonesia Arbitration Board (BAMUI). This abitration body was formed by the Majelis Ulama Indonesia- MUI- (Indonesian Ulema Council) based on MUI Decree No. Kep-09 / MUI XII / 2003 dated December 24, 2003 (Jamaludin, 2019). 
In accordance with Article 60 of Law Number 30 Year 1999 concerning Arbitration and Alternative Dispute Resolution, all decisions of sharia arbitration bodies are final and binding on the parties to the dispute. With the provision, if the decision of the Sharia arbitration body is not carried out voluntarily, then the decision can be carried out using the instrument of the head of the religious court at the request of one of the parties to the dispute. This provision is in accordance with the Surat Edaran Mahkamah Agung-SEMA (Supreme Court Circular) No. 08/2008. Two years later, precisely on May 20, 2010, the Supreme Court issued a new SEMA No. 08/2010 whose substance stated that the SEMA No. 08/2008 concerning Execution Decision of the Sharia Arbitration Board. The provisions contained in the SEMA refer to Article 59 paragraph (3) and explanation of paragraph (1) of Law Number 48 of 2009 concerning Kekuasaan kehakiman (Judicial Power).

The problem is not because of the issuance of the SEMA No. 08 of 2010, but the consideration that became the legal basis used as a reference in the SEMA. The existence of Article 59 paragraph (3) and the explanation of paragraph (1) of the Law on Judicial Power has eliminated the absolute authority of the Religious Court as previously regulated in Article 49 letter (i) of the Law on Religious Courts. This reality illustrates the disharmony and conflict of authority between the Religious Courts and the General Courts.

The unclear formulation of the two laws and regulations above caused many interpretations from both academics and law enforcement practitioners. This shows that the legislators are inconsistent in forming laws and regulations related to the resolution of Islamic economic disputes. These inconsistencies lead to legal conflicts between laws and regulations or can also be called legal antinomy.

\section{B. METHOD}

This research apply to the type of doctrinal legal research. Soerjono Soekanto said that the type is a normative legal research. Normative legal research includes research on legal principles, research on the degree of legal synchronization, and research on legal effectiveness(Soekanto, 2006). Benchmarks for normative legal research can be seen in terms of their nature and scope, namely prescriptive law and analytical law(Soekanto \& Mamudji, 1985). Prescriptive law analyzes law as something that is expected to be realized or should (das solen), whereas analytical law sees law as reality (das sein). Data collected in the form of legislation governing Islamic economic law disputes. The data is analyzed by content analysis method. The content analysis method is applied to look at the relationship between the laws and regulations in more depth

\section{RESULTS AND DISCUSSION}

\section{a. Theory of Authority, Legal Effectiveness and Antinomy of the Law}

This study applies the theory of authority, the theory of legal effectiveness in the form of application of laws, and the theory of resolution of legal conflicts. From these three theories, it can be clearly explained and disaggregated with which judicial institution has the authority in executing the decision of the Sharia Arbitration Board in Indonesia.

First, authority theory was popularized by SF. Marbun. In the Indonesian legal system, the granting of authority is the most important part that must be regulated by laws and regulations, both regulating the authority granted to public bodies, state institutions, and law enforcement agencies. The regulation is given in order to be able to conduct legal relations and legal actions in accordance with their functions while avoiding disharmony and overlapping authority among institution (Dotulong, 2018).

The authority that is often used in terms of the judiciary comes from the Dutch language, "competentie". This judicial competence involves two things, namely: "absolute competence" and "relative competence."(Mardani, 2011) Absolute competence or absolute authority of the court is the authority of 
the judiciary in examining certain types of cases which absolutely cannot be examined by a judiciary in another courts(Wahyudi, 2016). After the enactment of Law Number 3 of 2006, the absolute competence of the Religious Courts was expanded by including, among others, Islamic economics, as one area of competence. While the relative authority concerns the distribution of power to adjudicate between the same types of court depending on the place of residence of the defendant, in other words that the principle of relative authority is the actor sequator forum rei (the authority of the religious court where the defendant resides (Ivan S, 2016). If the object of the lawsuit on Islamic economic matters involves immovable objects, the lawsuit is submitted to the Religious Court which covers the jurisdiction where the immovable object is located (Nuraisyah, 2018). Further legal provisions regarding the relative competence of the Religious Courts are regulated in Article 118 HIR / Article $142 \mathrm{R} . \mathrm{Bg}$.

Second, the theory of the effectiveness of law in the application of laws and regulations proposed by Soerjono Soekanto. There are several factors that influence the effectiveness of a law including: 1) The substance of the legal substance which is the content of legislation regulations; 2) law enforcement factors; 3) facilities and infrastructure factors that support law enforcement; 4) community factors as legal subjects; and 5) legal cultural factors (Soekanto, 1983).

The five factors are benchmarks of the effectiveness of law enforcement or law enforcement related to the resolution of Islamic economic disputes in Indonesia. The most important thing is the factor of legal substance in the form of the regulatory material itself. The legal material of the written regulations must at least meet the requirements, namely: 1) systematic; and (2) harmonious. This means that there is harmony both vertically (hierarchical) and horizontally. So there is no disharmony between laws and regulations (Soerjono Soekanto, 1993).

Third, legal conflicts (the theory of legal antinomy) and theories about legal preferences in resolving conflicts between laws or laws. In the Big Indonesian Dictionary it is stated that antinomy is a controversial fact or in legal terms referred to as a conflict between two verses in the law. Based on the theory put forward by Gustav Radbruch, the existence of these laws and regulations should provide a sense of justice, certainty, and benefits to the people. This is a consequence for countries that adhere to the rule of law system(Mochtar, 2015).

In the research, antinomy is defined as a conflict between written legal norms, both between articles in the same law or between articles with different laws. To resolve conflicts between legal norms (legal antinomy), it can be resolved through the principles of legal preference. The legal settlement preference applies several legal maxim (legal rules). The legal rules used are: first, lex superiori derogat legi inferiori. This rule means that higher rules defeat lower rules; secondly, the lex specialis derogat legi generali principle. This rule means that the rules are more specific than the more general rules; and third, lex posteriori derogat legi priori, which is a new rule that erases old rules. These three rules of law are relevant to the concepts of tartib mashadir al-ahkam, takhsis al-'am, and naskh in the tradition of fiqh scholars(Taqiudin, 2017).

With the theories described above, the reality of legal conflict can be unraveled and find the root of the problem. The discovery of the root causes of this legal conflict is expected to help find solutions to legal conflicts.

\section{b. A Solution for the Antinomy}

Along with the growth and development of economic activities cultivated by business actors, various types of business cooperation were born which were bound by various agreements as well. This diversity of agreements can also be found in sharia-based business activities, especially those involving financing from Islamic financial institutions. Business agreements and financing that are carried out in a long time often give birth to legal events. This legal event occurred because of changes in conditions at the time this agreement was made. Conditions that change frequently cause the parties to not be able 
to meet the obligations agreed upon in advance. This reality is the beginning of a dispute. Disputes in business can occur due to deviations made by one of the parties so that there is a discrepancy between the agreement contained in the contract / agreement with practice. This deviation is caused by one of the parties defaulting or even committing an act against the law. Defaults can be caused by no good faith to carry out obligations, or due to delays in carrying out obligations and or due to erroneous implementation of obligations as stated in the deed of agreement made and agreed by the parties. While acts against the law can be caused by one party or both parties carrying out prohibited acts so that the consequences of these actions are harmed (Friska Muthi Wulandari, 2017).

Settlement of disputes that occur in business activities including sharia business can be resolved in accordance with the agreement of the parties as outlined in the agreement deed or written document, whether the agreement is made and agreed upon before the dispute arises or in legal terms often referred to as pactum de compromittendo or after the arising of the dispute acta compromis. Agreement in determining the choice in the agreement clause is an anticipatory form that must be present in the agreement deed. All agreements as outlined in the form of an agreement or 'contract are binding rules for the parties that made them. Therefore, all forms of agreement arising from the agreement have legal consequences. Settlement of disputes in sharia economics arising from defaults or unlawful acts that are detrimental to the parties or one of the parties can be done through procedures agreed upon by the parties as outlined in the agreement, such as settlement through the Alternative Dispute Resolution (ADR), through arbitration institutions or through the Religious Courts (Zulhefni, 2017).

Settlement of disputes through Alternative Dispute Resolution (ADR) such as negotiations, or the participation of third parties such as consultation and giving legal opinions, mediation and peace, and arbitration. Third party statements such as consultation and mediation are ways of resolving disputes through an interest based approach, such as managing disputes based on the interests or needs of the parties to the dispute, not looking at the position of each party. This solution is strived to reflect the interests of the disputing parties mutually so as to produce a win-win solution. Unlike the inclusion of a crime party through arbitration (tahkim), dispute resolution efforts in this way or often known as the right-based approach, the dispute resolution is even more based on the concept of rights (law), such as the concept of right and wrong. This concept is based on juridical parameters through adjudication procedures, such as dispute resolution in court. Right-based approaches like this generally lead to a state of win-lose solution (some parties are defeated) (Sudjana, 2018). If the parties agree to choose a dispute resolution effort through Alternative Dispute Resolution (ADR), the disputing party should refer to the deed of agreement that has been made, which can be seen in the anticipatory clause that points to the use of a third party, such as mediation, conciliation, and arbitration . Efforts to resolve disputes through Alternative Dispute Resolution (ADR) are actualization of the basic principles of civil law, namely freedom of contract (facta sun servanda). The legal provisions for the use of this principle are regulated in Article 1338 paragraph (1) of the Civil Code, in essence, that all contracts (agreements) made legally by the parties then serve as the law for those who make them.

If the negotiation or mediation method fails to reach an agreement, or the mediator fails to bring the two parties together, the parties can settle their dispute through the arbitration institution with the agreement of the parties contained in the agreement or written document. This is in accordance with Articles 4 and 5 of Law Number 30 Year 1999 concerning Arbitration and Alternative Dispute Resolution which states that, in the event that the parties have agreed that the dispute between them will be resolved through arbitration and the parties have given authority, the arbitrator is authorized determine in its decision regarding the rights and obligations of the parties if this is not stipulated in the agreement deed. Approval for resolving a dispute through arbitration shall be contained in a written document signed by the parties.

Further arrangements regarding the standard procedure for dispute resolution through sharia arbitration bodies are made and determined by the sharia arbitration body, no exception regarding the 
arrangement for one of the parties to submit a cancellation of the sharia arbitration body's decision. The procedure for filing an annulment of the award has been regulated in Article 71 of Law Number 30 of 1999, containing the reasons stipulated in the previous article, namely Article 70. An application for annulment of an arbitral award must be submitted in writing to the Chairperson of the Religious Court through the Clerk of the Religious Court a period of 30 (thirty) days from the submission and registration of the award.

The question is if the Sharia arbitration award is not carried out voluntarily, then the decision is carried out based on the order of the Chair of the Court? From this question raises many interpretations both among academics and legal practitioners. This is due to the Sharia arbitration body being unable to carry out the execution of its decision, because it is not a judicial body, so that a litigation institution authorized by the law is needed.

When looking at the legal basis used by the National Sharia Arbitration Board, the arbitration body uses the legal provisions regulated by Law Number 30 of 1999 concerning Arbitration and Alternative Dispute Resolution. Therefore, the execution of the said decision becomes the authority of the General Court. This is regulated in Article 61 of the Law on Arbitration and Alternative Dispute Resolution. In response to this polemic, the Supreme Court on October 10, 2008 issued a Supreme Court Circular Number 08 of 2008 concerning the Execution of the Sharia Arbitration Board's Decision. In Point Four (4) the circular states that basically the parties have agreed on the arbitration award. However, if the parties do not voluntarily pursue an award, one of the parties may ask the head of the religious court to make the decision and order the bailiff to execute the arbitral award. The substance of this provision is in accordance with the contents of article 49 of Law Number 3 Year 2006 concerning Religious Courts which confirms that the religious court has the authority to execute the decisions made.

Over time, the government in this case the legislative body (Dewan Perwakilan Rakyat/DPR) as the legislator passed Law Number 48 of 2009 concerning Judicial Power and Law Number 50 of 2009 concerning Second Amendment to Law Number 7 of 1989 concerning Religious Courts. With the issuance of the Law on Kekuasaan kehakiman (Judicial Power), which came into force on October 29, 2009, it has created a new polemic and leaves little question marks about the authority of the Religious Court in executing the BASYARNAS ruling. This is caused by the existence of Article 59 paragraph (3) and explanation of paragraph (1) of the Law on Judicial Power which states that, in the event that the parties do not implement arbitration decision (including Islamic arbitration) voluntarily, the decisions are carried out based on the Head of General Court at the request of one of the parties to the dispute.

To solve the dishamony with the legal authority, the Supreme Court of the Republic of Indonesia issued Supreme Court Regulation (Peraturam Mahkamah Agung/PERMA) Number 14 of 2016 concerning Procedures for Settling Sharia Economic Cases, then promulgated on December 29, 2016. The Supreme Court's consideration in issuing the PERMA was the reality that there was a binding relationship agreement. in sharia principles; the reality of the development of civil law requires a settlement procedure that meets the principles of justice namely simple, fast and low cost; and therefore the Supreme Court considers it necessary to make rules to cover the shortcomings or even the vacancy of the law in the Sharia economic dispute resolution procedures.

The PERMA contains 11 (eleven) chapters and 15 (fifteen) Articles. In Chapter XI regarding the Implementation of Decisions of Article 13 paragraph (2) and (3) of the Supreme Court Regulation Number 14 of 2016 concerning Procedures for Settling Sharia Economic Cases, it is stated that, the implementation of the Sharia arbitration award and annulment, shall be carried out by the Court within the religious court environment. Whereas the procedure for implementing the award referred to in paragraph (2) shall refer to Law Number 30 of 1999 concerning Arbitration and Alternative Dispute Resolution. 
PERMA emphasized that the authority to execute the decision of the Sharia arbitration body was to be the absolute authority of the religious court. This provision makes the form of harmonization of the provisions in Article 49 letter (i) of Law Number 50 Year 2009 concerning the Second Amendment to Law Number 7 of 1989 concerning Religious Courts. In this article it is stressed that the religious court has the authority to examine, decide upon and settle cases at the first level of people who are Muslims in the field of Islamic economics. The technicality of the execution of the vadan arbritase verdict itself is still subject to Law Number 30 of 1999 concerning Arbitration and Alternative Dispute Resolution.

Then, the question is, whetheer the District Court still given the authority to implement the BASYARNAS decision? The question arises because of the legal provisions contained in Article 59 paragraph (3) and explanation of paragraph (1) of Law Number 48 of 2009 concerning Judicial Power which gave birth to the dualism of the authority of the judiciary to implement the decision of the Sharia arbitration body. The existence of conflicting legal provisions between the authority of two judicial institutions under the Supreme Court as the perpetrators of judicial authority raises the existence of legal uncertainty.

The authority of the District Court in implementing Sharia arbitration body decisions in addition to being regulated in the Law on Judicial Power and the Law on Arbitration and Alternative Dispute Resolution, is also regulated in Article 50 of Law Number 49 Year 2009 concerning Second Amendment to Law Number 2 of 1986 regarding General Justice. In that article it is explained that: "The District Court has the duty and authority to examine, decide upon, and settle criminal cases and civil cases at the first level." These civil cases include: 1) regulations on humans as legal subjects, such as the ability to make agreements and the ability to conduct their own rights; 2) regulations regarding family law, such as marriage and all matters that have legal consequences due to marriage; 3) regulations regarding the law of wealth that can be valued in money; 4) inheritance law; and 5) regulations regarding matters carried out based on agreements or agreements such as sale and purchase agreements.

From this description it can be said that there are two judicial bodies that have the authority to execute the decisions of the arbitration body namely the state court and the religious court. The district court is given the authority to implement the decision of the Sharia arbitration body, governed by Article 59 paragraph (3) and explanation of paragraph (1) of Law Number 48 Year 2009 concerning Judicial Power. While the authority of the religious court is based on Article 49 letter (i) of Law Number 50 of 2009 concerning the Second Amendment to Law Number 7 of 1989 concerning Religious Courts. In this article it is stressed that "the Religious Courts have the duty and authority to examine, decide upon and settle cases at the first level of people who are Muslim in the field of Islamic economics." The article was then used as a legal basis by the Supreme Court in issuing PERMA Number 14 of 2016.

It is very clear that the article material of the two laws and regulations contradicts each other (the antinomy of the law). This condition can cause legal uncertainty for justice seekers. Though the material or legal content that should be contained in legislation must be able to realize order in society through guaranteed legal certainty. This is as regulated in Article 6 letter (i) of Law Number 12 of 2011 concerning Formation of Regulations and Regulations. Guaranteed legal certainty is the right of every person protected by the constitution, as stated in Article 28D paragraph (1) of the 1945 Constitution. The article states that, every person has the right to recognition, guarantee, protection, and certainty of fair law and fair treatment. same before the law. The existence of legal material contained in Article 59 paragraph (3) and explanation of paragraph (1) of Law Number 48 Year 2009 concerning Judicial Power, does not reflect order and guarantee legal certainty.

According to the theory of legal effectiveness, from Soerjono Soekanto which states that the effectiveness of law is one of which is determined by the substance of the law itself contained in the contents of the law. If the legal substance is not clear, then the legal function to give birth to justice, certainty and benefit will not be realized. Therefore, harmonization between laws and regulations 
becomes something that is inevitable. Harmonization is done to avoid the presence of material or legal content in overlapping laws and regulations. Harmonization efforts are aimed at making the existing laws and regulations complementary and interrelated. The regulations listed below can explain the regulations listed above as operational provisions. So that the substance of the regulatory environment can be executed systematically, effectively and efficiently (Novianto M. Hantoro, 2012). This harmonization is the alignment and harmonization of various laws and regulations related to the existing and currently existing legislation that regulates a particular field. The process of synchronizing regulations aims to see the harmony between one regulation and another. The synchronization is carried out both vertically with the regulations above and horizontally with equivalent rules.

The purpose of this harmonization is not as a regulatory basis in order to give birth to legal certainty that is adequate for the implementation of certain fields effectively and efficiently. According to Novianto, synchronizing legislation can be done in two ways: 1) vertical synchronization, carried out by looking at whether a statutory regulation that applies in a particular field does not conflict with each other with the laws or regulations above or more commonly known as hierarchy or levels in making laws and regulations. This is as explained in Article 5 paragraph (3) of Law Number 12 of 2011, namely the principle of conformity between types, hierarchy, and material content. In this provision, what is meant by "hierarchy" is the promotion of each type of lower statutory law that cannot contradict the lower statutory law which cannot contradict the higher statutory regulation. 2) horizontal synchronization, carried out by looking at various laws and regulations that are equal and regulating the same or related fields. Horizontal synchronization must also be carried out chronologically, in accordance with the timeline of the stipulation of the relevant laws and regulations. This is as explained in Article 6 paragraph (9) and (9) of Law Number 12 of 2011 concerning Formation of Regulations, namely the material contained in legislation must reflect the principles of order and legal certainty; and / or balance and harmony (Novianto M. Hantoro, 2012).

According to the theory above, Article 59 paragraph (3) and explanation of paragraph (1) of Law Number 48 Year 2009 concerning Judicial Power is not synchronous or not in harmony with the same statutory regulations, causing conflicts between laws and regulations or in other word it can be said as legal antinomy. This can be seen as follows: First, Article 59 paragraph (3) and explanation of paragraph (1) of the Law on Judicial Power is contradictory to Article 49 letter (i) of the Law on Religious Courts. This is due, the completion of the Islamic economic case before the birth of the Law on Judicial Power has clearly become the absolute authority of the Religious Court (See Article 49 letter (i) of Law Number 3 of 2006 concerning Religious Courts); Second, the District Court is not given the authority to settle Islamic economic cases. This can be seen in Article 50 of Law Number 49 Year 2009 concerning the Second Amendment to Law Number 2 of 1986 concerning General Courts. In that article it is explained that: "The District Court has the duty and authority to examine, decide upon and settle criminal cases and first level civil cases." Therefore, the delegation of authority to implement the decision of the Sharia arbitration body through Article 59 paragraph (3) and explanation of paragraph (1) of the Law on Judicial Power is not in line with the absolute authority of the District Court.

To resolve the legal conflict above, it can be analyze in two ways: First, through the principle of preference for resolving conflicts between laws and regulations. This principle explains that, if there is material content between conflicting laws and regulations (different levels or hierarchies), then the lex superiori derogat legi inferiori principle applies. This means that higher rules can defeat lower rules. If the conflict of rules is to the same degree then another principle applies, namely lex specialis derogat legi generali. Specific rules are stronger than general rules. So if the two contradict each other then the general rules can be set aside for the implementation of specific rules. Second, submit an application for judicial review to the Constitutional Court. The constitutional court is given the authority to examine the law against the Basic Law. Decisions of the Constitutional Court may result in the entire contents of 
the law having no binding legal force, or one part of the material contained in the law such as article, paragraph, article explanation and / or paragraph explanation does not have binding legal force.

According to the analysis before, it can be said that, the settlement of legal conflicts between Article 59 paragraph (3) and explanation of paragraph (1) of the Law on Judicial Power with Article 49 letter (i) of the Law on Religious Courts, can use the principle of lex specialis derogat legi generali. The reasons are firstly, Law Number 48 Year 2009 concerning judicial power generally applies to regulate all judicial bodies under the Supreme Court as the perpetrators of judicial power (lex generali). Whereas Law Number 03 of 2006 concerning Amendment to Law Number 7 of 1989 concerning Religious Courts applies specifically to regulate the duties and authority of the Religious Courts (lex specialis). Secondly, the District Court was not given the authority to settle Islamic economic cases. This can be seen in Article 50 of the Law on General Courts. Whereas the Religious Court is given the authority to settle Islamic economic matters. This can be seen in Article 49 letter (i) of the Law on Religious Courts. In addition to using the above principle, it can also be through an application for judicial review to the Constitutional Court. Legal reasons for the application for judicial review of Article 59 paragraph (3) and explanation of paragraph (1) of the Law on Judicial Power, because it is contrary to Article $28 \mathrm{D}$ paragraph (1) of the Constitution 1945.

\section{CONCLUSION}

Settlement of antinomy (legal conflict) between Article 59 paragraph (3) and explanation of paragraph (1) of the Law on Judicial Power with Article 49 letter (i) of the Law on Religious Courts, can use the principle of lex specialis derogat legi generali. The reason is because: First, Law Number 48 Year 2009 concerning Judicial Power generally applies to regulate all judicial bodies as perpetrators of judicial power as a general law (legi generali). Whereas Law Number 50 Year 2009 concerning Second Amendment to Law Number 7 Year 1989 concerning Religious Courts (lex specialis). The second reason, the District Court was not given the authority to settle Islamic economic cases. This can be seen in Article 50 of the Law on General Courts. Whereas the Religious Court is given the authority to settle Islamic economic matters. This can be seen in Article 49 letter (i) of the Law on Religious Courts. In addition to using the above principle, it can also be through an application for judicial review to the Constitutional Court. The legal reasons for the application for judicial review of Article 59 paragraph (3) and explanation of paragraph (1) of the Law on Judicial Power, because it is contrary to Article 28D paragraph (1) of the 1945 Constitution.

\section{E. ACKNOWLEDGMENTS}

Authors would like to express their deep and sincere gratitude to LP2M UIN Sunan Gunung Djati Bandung Ministry of Religion of the Republic of Indonesia for providing funds for this research in 2019.

\section{REFERENCES}

Dotulong, S. (2018). Analisis Yuridis Keputusan Tata Usaha Negara yang Dikeluarkan Tanpa Wewenang sebagai Objek Gugatan di Pengadilan Tata Usaha Negara. Jurnal Lex Administratum, VI(4).

Fathurrahman Djamil. (2006). Prinsip-prinsip Ekonomi Islam. Dalam Kapita Perbankan Syariah Atas UUNo. 7 tahun 1989 (Perluasan Wewenang Peradilan Agama). Mahkamah Agung RI.

Friska Muthi Wulandari. (2017). Dualisme Peraturan tentang Kewenangan Pengadilan Terhadap Eksekusi Putusan Badan Arbitrase Syariah Nasional. Tesis Pada Program Studi Hukum Islam UIN Sunan Kalijaga Yogyakarta.

Ivan S, R. (2016). Tinjauan Yuridis tentang Peranan Identitas Domisili dalam Menentukan Kompetensi Relatif Pengadilan. Jurnal Lex Privatum, IV(1). 
Jamaludin. (2019). Penyelesaian Sengketa Wakaf Melalui Basyarnas. Jurnal Misykat al-Anwar, 30(1).

Manan, A. (2017). Hukum Ekonomi Syariah: Dalam Perspektif Kewenangan Peradilan Agama. Prenada Media.

Mochtar, Z. A. (2015). Antinomi dalam Peraturan Perundang-undangan di Indonesia. Hasanuddin Law Review, 1(3), 316-336. https://doi.org/10.20956/halrev.v1i3.112

Novianto M. Hantoro. (2012). Sinkronisasi dan Harmonisasi Hukum Penyelenggaraan Otonomi Daerah: Studi di Provinsi Bali. P3DI Setjen DPR Republik Indonesia dan Azza Grafika.

Nuraisyah. (2018). Peranan Hakim Pengadilan Agama dalam Penerapan Hukum Islam di Indonesia. Jurnal Al-Qada', 5(1).

Soekanto, S. (1983). Faktor-faktor yang mempengaruhi penegakan hukum. Rajawali.

Soekanto, S. (2006). Pengantar penelitian hukum. Penerbit Universitas Indonesia (UI-Press).

Soekanto, S., \& Mamudji, S. (1985). Penelitian hukum normatif: Suatu tinjauan singkat. Rajawali.

Soerjono Soekanto. (1993). Penegakan Hukum. Bina Cipta.

Sudjana. (2018). Efektivitas dan Efisiensi Penyelesaian Sengketa Kekayaan Intelektual melalui Arbitrase dan Mediasi Berdasarkan Undang-Undang Nomor 30 Tahun 1999. Jurnal Ajudikasi, 2(1).

Taqiudin, H. U. (2017). Penalaran Hukum (Legal Reasoning) dalam Putusan Hakim. Jurnal IImu Sosial dan Pendidikan, I(2).

Wahyu Widiana. (2007). Kumpulan Makalah Ekonomi Syariah. Mahkamah Agung RI Direktorat Jenderal Badan Peradilan Agama.

Wahyudi, A. T. (2016). Kewenangan Absolut Peradilan Agama Di Indonesia Pada Masa Kolonial Belanda Hingga Masa Pasca Reformasl. Jurnal Yudisia, VII(2).

Zulhefni, M. (2017). Kendala Penyelesaian Sengketa Perbankan Syariah melalui Pengadilan Agama Kota Malang. Jurnal Jurisdictie, 8(2). 